\title{
Development of North Sumatera History Textbooks Based on Six Task KKNI in First Semester College Student at History Education Department
}

\author{
Lister Eva Simangunsong ${ }^{1}$ Rosmaida Sinaga ${ }^{2}$, Ronald Simarmata ${ }^{3}$ \\ \{listeresimangunsong@unimed.ac.id ${ }^{1}$,rosmaidasinaga@unimed.ac.id ${ }^{2}$. \\ Ronaldsimarmata16@gmail.com\}
}

Universitas Negeri Medan, North Sumatera, Indonesia ${ }^{1,2,3}$

\begin{abstract}
Textbooks are very important to be developed as an effort to increase learning quality, especially on North Sumatra History subject in History Education Department. Development of these North Sumatra History textbooks arranged from the college students' assignments such as paper, presentation, engineering ideas, journal review, mini-research and project which implemented during the one-semester learning process. This research using Research and Development method (R\&D). R\&D is a research method used to generate some products and to test its effectivity. This research was designed using Walter Dick and Lou Carey's development model with five procedural steps, which is: analyze, developing, design, implementation, and the last is evaluation. This development specifically intend to developing the learning and teaching process and generating the college student creation, which is North Sumatera History Textbooks, so that the textbook which uses no more dominated by the outside publisher, but by the student creation themselves
\end{abstract}

Keywords: Development, North Sumatera History Textbooks, KKNI.

\section{Introduction}

As a character-building university, the state university of Medan has been applied curriculum based on KKNI since the 2016/2017 school year. Constitution Number 12, the year 2012 chapter 35 mandates that the college's curriculum developed by every College program, which is developing intellectual intelligence, nobility, and skill. Next, based on National Education Minister No. 16, the year 2012, mandate that curriculum in every education level in Indonesia referred to Indonesia's National Framework Qualification, also known as KKNI (Kerangka Kualifikasi Nasional Indonesia). In KKNI was made mechanism side by side with employee's qualification which now on needed to solving unemployment's problems which caused by unrecognition of someone's competition. For that, Recognition of Prior Learning/RPL's mechanism nor Recognition of Current Competency now on, KKNI is very needed to become a strategy formal service, nonformal, even from work experience.

Referring to the IQF, Strata 1 level is at level 6 to improve the quality of its graduates especially in implementing learning, then the State University of Medan applies the KKNI learning model. Where the study of the IQF provides a concept in making assignments. There 
are 6 tasks in KKNI, including Routine Tasks, Critical Book Report, Critical Journal Review, Mini Research, Engineering Ideas, and the last is Project.

Under the title in this study, the implementation of this IQF should be seen in every lecture agenda at Medan State University. The History Education Department has implemented this curriculum in its implementation in lectures, especially in the History of North Sumatra course. That the history of North Sumatera has an important role in the formation of National History of the people of the time in the past which are not yet known to the wider community[4]). Even the ethnicity of a tribe and region can be seen from the course of its history [3]. History of North Sumatra is a subject that must be followed by students of the Department of History Education in semester 1 with a weight of SKS 2. Through KKNI it is hoped that there is significant progress in student achievement so that they can enter the world of labor, competitive, and creative competitiveness, and innovative.

Based on the above background, the problem that arises is how to develop teaching books based on KKNI in the History of North Sumatra course in the History Education Department in semester 1 students of 2019/2020 Academic Year? The purpose of writing this scientific work is to develop a textbook based on KKNI in the History of North Sumatra course in the Department of History Education in semester 1 students of the 2019/2020 Academic Year. The expected outcome of this study is the book ISBN History of North Sumatra. The additional outputs of this research are Scientific Articles published in Indexed Proceedings.

\section{Methods}

The method used in this research is the research and development method. Development research methods are methods used to produce certain products and test the effectiveness of these products [6]. Research and development is a process or steps to develop a product or improve existing products that can be accounted for [7]. The process of developing instructional media in the form of this Textbook uses the research and development (R\&D) model by Borg and Gall (2003) (in Gooch, 2012: 86). The stages of the R\&D model include: (a) Requirement Analysis Phase, (b) Product Design, (c) Production/Implementation of Initial Product Development, (d) Validation, (e) Revision, (f) Product Trial, (g) Final Revision and dissemination.

The population in this study were students of the Department of History Education in Academic Year 2019/2020 who took the History of North Sumatra course. The sampling technique used in this stage is purposive sampling. This technique is a way of taking samples based on specific considerations or goals [2]. Sampling also uses purposive sampling, namely students of the Department of History B Regular 2019 class. Data collection techniques used in this study were questionnaire or questionnaire, observation, interview, and document study techniques. The instruments used in this study were questionnaires for material experts, for media experts, as well as for students. Instrument testing is done using content validity, which compares the contents of the instrument with existing theories. Data analysis in this study was carried out with qualitative analysis techniques and quantitative analysis. 


\section{Result and discussion}

The results of the research development of the North Sumatra Historical Textbook as a history learning textbook will be described based on the steps of Walter Dick and Lou Carey's development grouped into four stages, namely: preliminary studies, development, field testing, and dissemination and dissemination of final products. The results of the study are described as follows.

The learning process of the History of North Sumatra in the Department of Historical Education still encountered various obstacles. Based on the results of preliminary observations carried out, it was revealed that learning activities so far tended to be less innovative and did not utilize the potential of student writing. Based on the results of interviews with Regular Class A, 8 out of 10 students claimed that the assignments carried out so far were not optimal because the results of the assignment were not utilized.

The results of interviews with North Sumatra History lecturers revealed that the scores achieved by students for North Sumatra history courses were relatively unsatisfactory. This was an indication that the material in the North Sumatra history course had not been well absorbed by students. Other existing literature books also have not been able to arouse student learning motivation because of the presentation of material that is less innovative. So that students are more motivated for assignments and learning, one way to do this is by utilizing what students have done. Seeing that so far students have not been optimal in the implementation of the six KKNI assignments, the development of the North Sumatra History Textbook was conducted based on the assignments of the students. In addition to this, this development is also carried out so that students develop more competitive power in the execution of tasks, it is intended that these tasks can be more weighty and worthy to be developed.

The purpose of writing this scientific work is to produce textbooks based on KKNI in the North Sumatra History course that can increase motivation and help the learning process of students. Capability analysis consists of estimating the funds, energy and time needed to conduct research. The use of funds is made as efficient as possible. The funds used in the procurement of textbooks are for the cost of printing the book. The time needed to complete the study is approximately six months.

The developed product is a textbook that covers all the material contained in the contract of the North Sumatra history course. The material is presented using text and several picture illustrations related to each material. The form of the book is presented in the form of a printed book. The illustrations are supported with a brief narrative to clarify the picture's description. This product is designed as a book that does not require other facilities and infrastructure in its use. The textbook can be read whenever and wherever students are, including being used for self-study by students outside the classroom. Before the product is tested in the field, the product is validated first with media experts and textbook experts. Expert validation is carried out so that the textbook products developed to get a guarantee that the initial product developed is worth testing out for students[5].

The expert lecturer in the material in the product validation of the textbook "North Sumatra History" is Dr. Lukitaningsih, M.Hum., Lecturer at the State University of Medan's History Education Department. The assessment is done by providing a textbook product along with a questionnaire evaluation sheet filled out by material expert lecturers. The assessment sheet questionnaire contained 22 points about the suitability of the curriculum, the correctness of the contents, and the way they were presented. Rating for each indicator uses a rating scale from 1 to 5 with the following criteria. 
SK (Very Less) has a score of 1

$\mathrm{K}$ (Less) has a score of 2

$\mathrm{C}$ (Fair) has a score of 3

B (Good) has a score of 4

SB (Very Good) has a score of 5

The validation process for material experts is carried out twice the first stage of material expert validation is done by submitting the textbook along with the assessment sheet to the material expert lecturers. To provide a clearer picture of the results of the first and second stages of expert material validation, the acquisition of scores is presented in the following diagram.

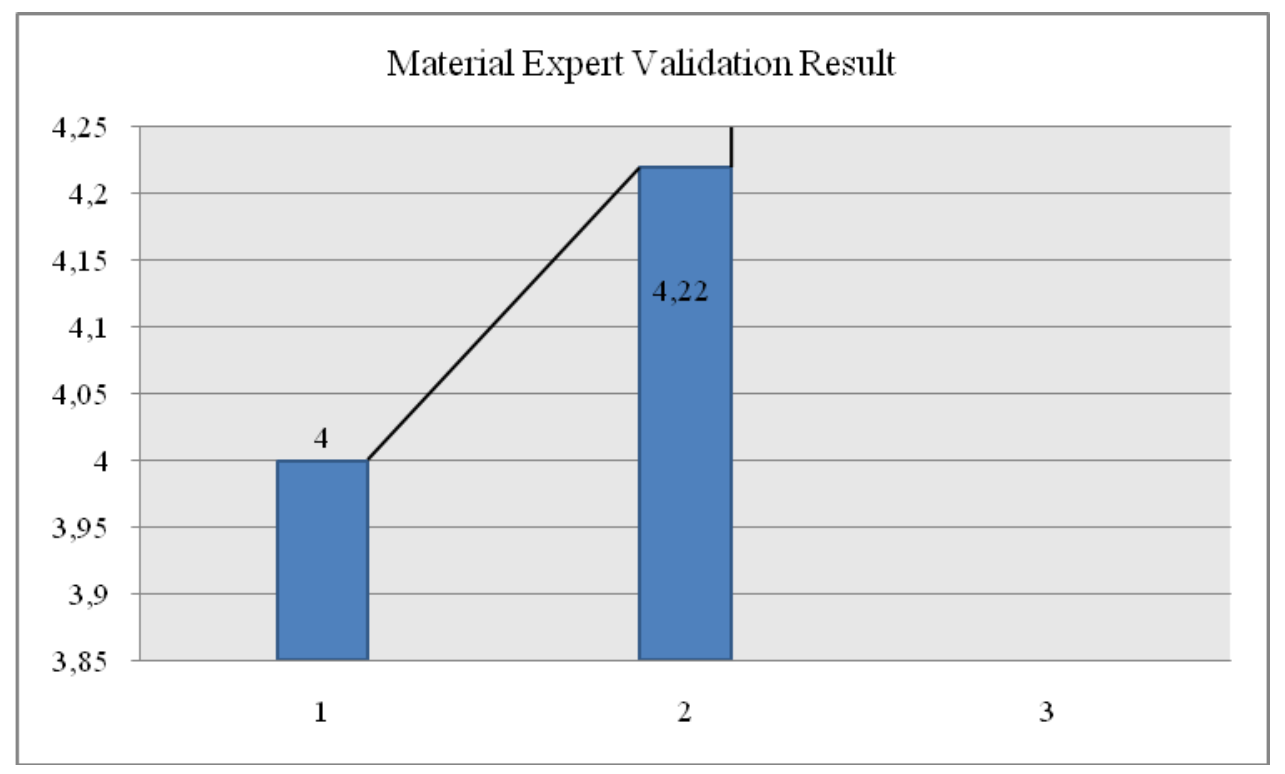

Fig. 1. Material Expert Validation Result

Seen in the diagram an increase in the average rating score from 4.00 in the first stage of assessment to 4.22 in the second stage of assessment. The average score of 4.22 in the second stage of assessment in the conversion of Qualitative to Quantitative data is in the average range> $3.4-4.3$ so it is included in the "good" category. Based on the research provisions that the developed textbook is said to be feasible if minimally included in either category, then products are said to be feasible in terms of material. This is reinforced by the statement of material experts that the developed products are worth testing. In addition to passing validation with material experts, the developed book is also validated by book experts.

The textbook expert in the validation of textbook products is Syarifah, a lecturer at the State University of Medan's History Education Department. Textbook expert validation is done by providing products along with assessment sheets. The assessment sheet is in the form of a questionnaire with 28 items regarding production criteria, visual design, and technical quality. Assessment for each indicator uses a rating scale from 1 to 5 with the following criteria: 
SK (Very Less) has a score of 1

$\mathrm{K}$ (Less) has a score of 2

$\mathrm{C}$ (Fair) has a score of 3

B (Good) has a score of 4

SB (Very Good) has a score of 5

The validation process for media experts was carried out three times. An indirect assessment was carried out at that time, product experts asked for time to study products that were developed first and then were given an assessment. Based on the guidelines for converting quantitative to qualitative data, the average value of textbook media developed at the third stage of assessment is included in both criteria. The expert product lecturer stated that the textbook could be tried out in the field without revision. To provide a clearer picture of the results of the assessment of product experts from the first stage to the third stage, it can be seen in the following diagram.

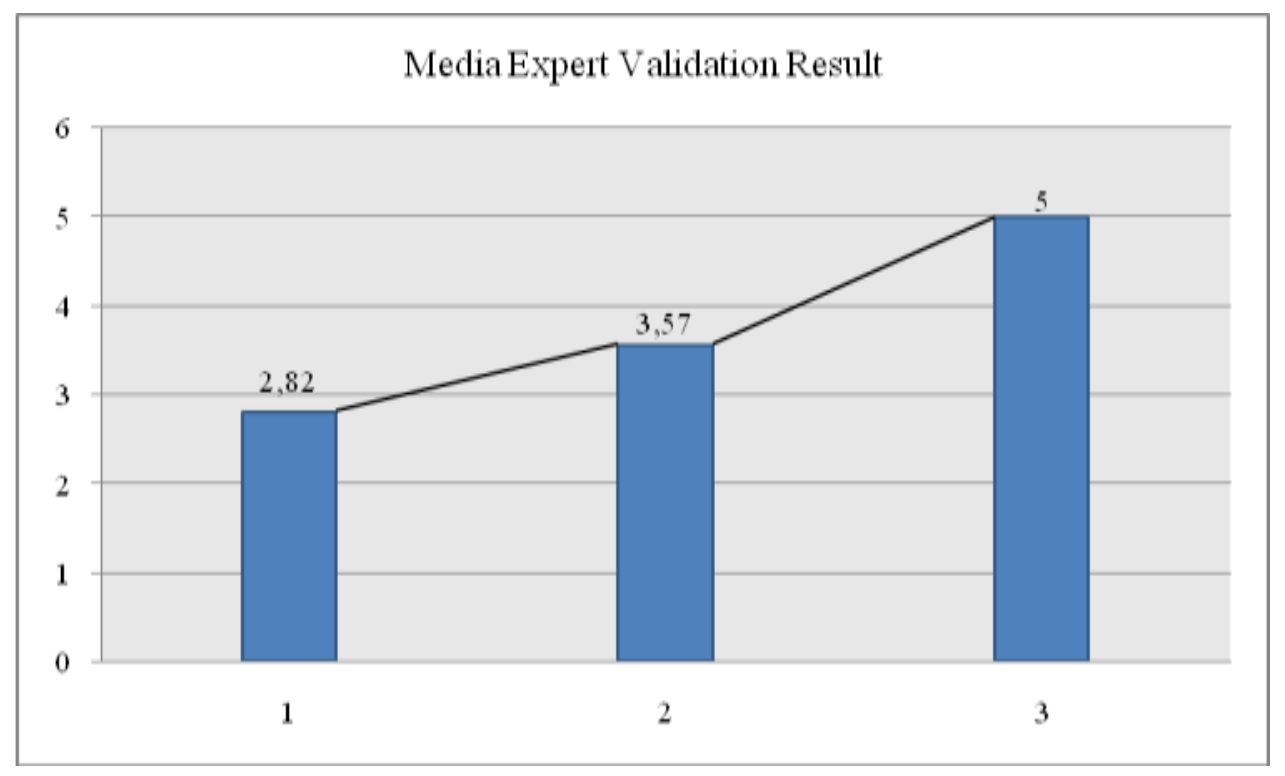

Fig. 2. Media Expert Validation Result

During the product expert validation process in the three stages of the textbook expert assessment with two product revisions, it was seen that the average value of the textbook increased from 2.82 in the first stage assessment, 3.57 in the second stage assessment, and 5.00 in the third stage assessment. The average score of 5.00 in the third stage of expert material assessment in the table of quantitative data conversion to qualitative data is included in the interval> $3.4-5.00$ so it is included in the category of "good". Based on the research provisions that textbook products are considered feasible if minimally included in either category, then the products are feasible in terms of textbook consideration. This is reinforced by the statement of product experts that the developed products have been worth testing. Products that have passed the validation stage of material experts and product experts and have been declared feasible, then these media products can already be tested on students. 
Field tests on the Textbook product were conducted on Student B Regular 2019. The trials were carried out in three stages, namely limited field tests, wider field tests, and operational tests [1]. The limited field test was carried out by taking a sample of three students from 2019 Regular A students as respondents. Students taken as a sample are selected who have a high intellectual level, moderate, and less. Respondents were given a textbook product to read. After the respondent finished reading the textbook, students were asked to give an assessment using a questionnaire. The questionnaire contains a statement that must be filled in by the respondent with five answer choices, namely:

STS: Strongly Disagree (Score 1)

KS: Not Agree (Score 2)

$\mathrm{C}$ : Enough (Score 3)

S: Agree (Score 4)

SS: Strongly Agree (Score 5)

From this table, the average value of 4.20 was obtained from the results of student evaluations of products. Based on the table of quantitative to qualitative data conversion, the textbook developed is included in the good criteria. In addition to the assessment, a questionnaire is done by observing limited field tests. A broader field test was conducted involving six students in the Regular A 2019. Six students taken as respondents were chosen with various intellectual levels from high to low. Respondents were given textbooks and then asked to fill out the questionnaire provided. Based on the table above, it obtained an average rating of 4.26 respondents. Based on the quantitative to qualitative data conversion table, the textbook product developed is included in very good criteria.

At the final product trial stage, an operational test is conducted involving all 2019 Regular A students. Like the previous field test stage, the student operational textbook is distributed with a textbook to read then students are asked to provide an assessment with a questionnaire. Then the average value of the respondent's assessment is 4.13. Based on the table of quantitative to qualitative data conversion, the textbook product developed is included in the gooD criteria. The results of conducting field trials on textbook developed more clearly are presented in the following bar diagram 


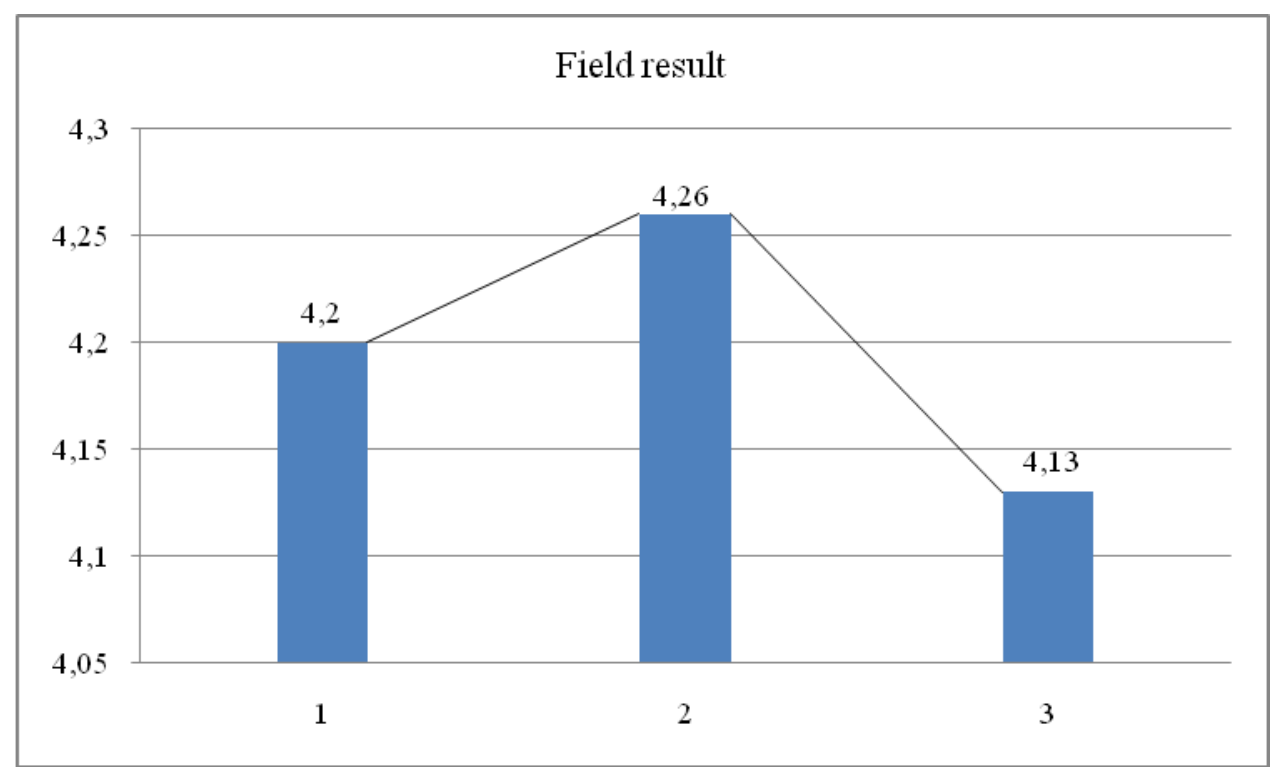

Fig. 3. Broad Field Test

In the diagram, it appears that the average assessment score at each stage of the trial is not far adrift. According to the guidelines for converting quantitative data to qualitative acquisition the average score of 4.2 in the limited field test is at intervals> $3.4-4.2$ so that it includes the criteria of "good". The average score of 4.26 in the field test stage is broader at intervals> 4.2 so it includes the criteria of "very good". While the average score of 4.13 at the operational test stage is at intervals> $3.4-4.2$ so that it includes the criteria of "good". Thus, the developed products are appropriate to be used based on the stipulation that textbook products are considered feasible if at least the assessment results are included in the "good" criteria.

Based on the results of data analysis on the results of the validation of material experts conducted in two stages with one revision, an average score of 4.00 was obtained in the first stage assessment and 4.22 in the second stage assessment. The average score of material expert judgments obtained by the developed textbook product is included in the "good" criteria according to the guidelines for converting quantitative data to qualitative data[8]. Under the provisions of the study that products are said to be feasible if the minimum average score includes good criteria, then the product developed is feasible in terms of the content of the material. The feasibility of the textbook is supported by the statement of the material experts that the products have been worth tested in material terms.

Whereas the validation of textbook experts was carried out in three stages, with two revisions. The average scores obtained are 4.194 .26 , and 4.14, respectively. The average score obtained at the first stage of assessment according to the guidelines for the conversion of quantitative data to qualitative[8].is included in the "sufficient" criteria. While the average score obtained at the second and third stages of assessment included in the category of "good". Under the provisions of the study that products are said to be feasible if the average minimum score includes good criteria, then the textbook developed are feasible in terms of textbook considerations. The textbook developed is under the curriculum, learning indicators taken. The 
product of textbooks that have been developed has been well viewed from indicators of curriculum suitability with an average score of 5.00. Seen from the true indicators of content, the material in the textbook product is good with an average score of 5.00. Furthermore, in terms of technical quality with good product requirements indicators, the textbook includes good criteria with a score of 4.20. Good product requirements assessment items include the ability to motivate students, make it easier for students to remember, make the presentation of material interesting and ease of use.

A textbook that has received appropriate recommendations from material experts and media experts are eligible to be tested in the field. The average score for acquisition in the field test stage is limited, wider field test and operational test respectively 4.19, 4.26 and 4.14 with good, very good, and good categories. The results of observations made at the three stages of the field test show that the textbook product developed in the pilot phase looks able to attract students to read the textbook. Student interest in learning resources is a good symptom for improving student learning achievement.

\section{Conclusion}

Based on the results of research and discussion, it can be concluded that the development of the North Sumatra History Teaching Book refers to the Borg and Gall development stage which is grouped into four stages, namely preliminary studies, development, field testing, as well as product dissemination and dissemination. The textbook that is developed quantitatively and qualitatively is suitable for use in learning. The feasibility of the textbook is shown by the material expert judgment of 4.22 which is included in the category of "good" and the assessment of the media expert of 5.00 which is included in the "very good" criteria. While the assessment of students in the field testing stage is limited, wider field tests, and operational tests respectively $4.20 ; 4.26$; and 4.13. A value of 4.20 in the field test is included in the "good" criteria, a value of 4.26 in the field test is broadly included in the "very good" criteria, and a value of 4.13 in the operational test is included in the "good" criteria. The developed textbook can increase student motivation and interest in learning historical material and facilitate student learning.

\section{References}

[1] Akbar, S. (2013). Instrumen Perangkat Pembelajaran. Bandung: Remaja Rosdakarya.

[2] Arifin, Z. (2009). Evaluasi Pembelajaran. Bandung: PT. Rosdakarya.

[3] Loeb, E. (2013). Sumatra: Sejarah dan Masyarakatnya. Yogyakarta: Penerbit Ombak.

[4] Marsden, W. (2008). Sejarah Sumatera Utara. Jakarta: Komunitas Bambu.

[5] Nuha, U. dkk. (2016). Pengembangan Buku Ajar Berbasis Penelitian Evolusi dan Filogenetik Molekuler Untuk Mata Kuliah Evolusi di Universitas Jember. Jurnal Pendidikan, 1, 1791-1996.

[6] Sugiyono. (2011). Metode Penelitian Kualitatif, Kuantitatif, dan R\&D. Bandung: Alfabeta.

[7] Sukmadinata, N. S. (2013). Metode Penelitian Pendidikan. Bandung: Remaja Rosdakarya.

[8] Widoyoko, E. P. (2009). Evaluasi Program Pembelajaran. Jakarta: Pustaka Pelajar. 